University of Nebraska - Lincoln

DigitalCommons@University of Nebraska - Lincoln

Faculty Publications from the Harold W. Manter Laboratory of Parasitology

6-1997

\title{
Eimeria (Protozoa: Eimeriidae) from North American Sciurids, Glaucomys sabrinus and Tamias townsendii: With a Description of a New Species
}

\author{
Claire A. Fuller \\ Oregon State University \\ Donald W. Duszynski \\ University of New Mexico, eimeria@unm.edu
}

Follow this and additional works at: https://digitalcommons.unl.edu/parasitologyfacpubs

Part of the Parasitology Commons

Fuller, Claire A. and Duszynski, Donald W., "Eimeria (Protozoa: Eimeriidae) from North American Sciurids, Glaucomys sabrinus and Tamias townsendii: With a Description of a New Species" (1997). Faculty Publications from the Harold W. Manter Laboratory of Parasitology. 168.

https://digitalcommons.unl.edu/parasitologyfacpubs/168

This Article is brought to you for free and open access by the Parasitology, Harold W. Manter Laboratory of at DigitalCommons@University of Nebraska - Lincoln. It has been accepted for inclusion in Faculty Publications from the Harold W. Manter Laboratory of Parasitology by an authorized administrator of DigitalCommons@University of Nebraska - Lincoln. 


\title{
EIMERIA (PROTOZOA: EIMERIIDAE) FROM NORTH AMERICAN SCIURIDS, GLAUCOMYS SABRINUS AND TAMIAS TOWNSENDII: WITH A DESCRIPTION OF A NEW SPECIES
}

\author{
Claire A. Fuller* and Donald W. Duszynski† \\ Department of Zoology, Oregon State University, Corvallis, Oregon 97331-2914
}

\begin{abstract}
From 1990 to 1991,11 northern flying squirrels, Glaucomys sabrinus, and 30 Townsend's chipmunks, Tamias townsendii, were live-trapped, marked, and released in MacDonald Forest, Benton Co., Oregon and their feces at each capture examined for the presence of coccidian parasites. Two eimerians were found in G. sabrinus: Eimeria dorneyi and a second species we describe here as new. One species, Eimeria vilasi, was identified from $T$. townsendii. Sporulated oocysts of the new eimerian are strongly ellipsoidal, pointed at 1 end, and are $47.2 \times 25.0(41-52 \times 22-31) \mu \mathrm{m}$ with ovoidal sporocysts, $19.0 \times$ $10.5(17-21 \times 9-11) \mu \mathrm{m}$. A micropyle and oocyst residuum are absent, but, occasionally, a polar granule is present in the oocyst. In the sporocysts, Stieda and substieda bodies are present, as is a membrane-bound residuum. Sporulated oocysts of $E$. dorneyi are uniformly ellipsoidal, $23.0 \times 14.7(17-26 \times 13-16) \mu \mathrm{m}$ with elongate ellipsoidal sporocysts, $11.6 \times 5.7(9-13 \times 5-7) \mu \mathrm{m}$. A micropyle and oocyst residuum are absent, but 1 polar granule is present. A Stieda body is present, but sub- and parastieda bodies are absent. The sporocyst residuum is composed of granules in a compact mass. Here we provide phototype (hapantotype) specimens archived in a nationally accredited museum and a line drawing (cartoon) to supplement the one provided by Soon and Dorney because their drawing did not show the sporocyst residuum given in the written description.
\end{abstract}

The Sciuridae (squirrels and their relatives) comprise 50 genera with 273 species (Wilson and Reeder, 1993), but only 16 of these genera have had 1 or more of their species examined as possible hosts for coccidia. The squirrels are divided into 2 subfamilies, the Pteromyinae (14 genera, $43 \mathrm{spp}$.) and the Sciurinae (36 genera, $230 \mathrm{spp}$.). In this study we had the opportunity to examine feces from Glaucomys sabrinus Shaw, 1801 and from Tamias townsendii Bachman, 1839, a member of each subfamily, respectively. In a companion study, in which we are examining all coccidian species described from the Marmotini tribe of the Sciurinae to determine which are valid species and which are not (P. Wilber, unpubl. obs.), we have noted that (1) many "species" do not meet minimal criteria for a species description under the International Code of Zoological Nomenclature (Ride et al., 1985); (2) several "species" have been described several times, but given different names; and (3) many valid species occur in multiple hosts. In this study, we name 1 new species and provide mensural data and type material on a second species to retain the name Eimeria dorneyi Levine and Ivens, 1965.

\section{MATERIALS AND METHODS}

Hosts were live-trapped at 1 site in MacDonald Forest at 2-5-wk intervals from 8 July to 14 September 1990 and from 30 March to 6 October 1991. Fecal samples from G. sabrinus were only examined in 1990. Rodents were individually marked and released. Feces were collected from traps to examine for the presence of coccidia. Fecal samples were weighed and allowed to sporulate at least 6 days at room temperature $(20 \mathrm{C})$ in $2.5 \%$ aqueous $(\mathrm{w} / \mathrm{v})$ potassium dichromate $\left(\mathrm{K}_{2} \mathrm{Cr}_{2} \mathrm{O}_{7}\right)$, then examined by flotation in Sheather's sugar solution (Ash and Orihel, 1987). Samples of all Eimeria oocysts were measured with an ocular micrometer and photographed with Panatomic-X $35 \mathrm{~mm}$ film with a Zeiss Universal photomicroscope equipped with neofluor and Nomarski-interference contrast $100 \times$ objectives. All measurements are in $\mu \mathrm{m}$ with means in parentheses following the ranges. Oocysts were $\leq 2 \mathrm{mo}$ old when examined.

Received 15 July 1996; revised 16 December 1996; accepted 16 December 1996.

* Current address: Division of Science \& Mathematics, University of the Virgin Islands, St. Thomas, Virgin Islands 00802.

$\dagger$ Department of Biology, University of New Mexico, Albuquerque, New Mexico 87131
DESCRIPTION

Eimeria dorneyi Levine and Ivens, 1965

(Figs. 1-3, 7)

Oocysts uniformly ellipsoidal (Figs. 1, 2) with 2 wall layers, $\sim 1.0$ 1.3, of equal thickness, outer layer smooth, not sculptured; micropyle and oocyst residuum are absent, but 1 highly refractile polar granule present, which varies in shape, $\sim 1.5$ long (Fig. 3); sporulated oocysts $(\mathrm{N}=16) 17-21 \times 13-16(23.0 \times 14.7)$ with $\mathrm{L}: \mathrm{W}$ ratio $1.6(1.4-1.7)$; sporocysts $(\mathrm{N}=16)$ elongate-ellipsoidal (Fig. 1), 9-13 $\times 5-7(11.6 \times$ 5.7) with $\mathrm{L}: \mathrm{W}$ ratio $1.8-2.1$ (2.0); Stieda body present, prominent, but sub- and parastieda bodies are absent; sporocyst residuum of compact granules, $\sim 3 \times 4$, and may be membrane bound; sporozoites with highly granular cytoplasm and 1 large, posterior refractile body.

\section{Taxonomic summary}

Type host: Glaucomys sabrinus macrotis, northern flying squirrel (Dorney, 1962).

Type locality: U.S.A., Wisconsin, Vilas County near Trout Lake (Dorney, 1962).

Other localities: Canada, Ontario, University of Waterloo campus (Soon and Dorney, 1969); U.S.A., Oregon, Benton County, MacDonald Forest (this study).

Prevalence: Found in $1 / 1$ G. sabrinus in Wisconsin, $2 / 2$ G. sabrinus in Ontario, and $1 / 11(9 \%) G$. sabrinus in Oregon (this study); it was subsequently found in 2 other Oregon $G$. sabrinus recaptured at a later date.

Sporulation time: Within $1 \mathrm{wk}$ at room temperature $(20 \mathrm{C})$, this study.

Material deposited: Phototype (see Bandoni and Duszynski, 1988) of sporulated oocysts in the U.S. National Parasite Collection (USNPC), Beltsville, Maryland, no. 86934. Symbiotype (see Frey et al., 1992) of this host was not collected as all hosts were marked and released after capture.

\section{Remarks}

Dorney (1962) caught 1 G. sabrinus macrotus and found it was discharging oocysts that he thought fit the description of Eimeria sciurorm Galli-Valerio, 1932; however, the original description of E. sciurorm from Sciurus vulgaris (Galli-Valerio, 1932) was so incomplete that it warranted the status of either species inquirenda or nomen dubium (depending upon your interpretation of these definitions in the International Code of Zoological Nomenclature; Ride et al., 1985). Because of this and the assumption that sciurids in different subfamilies can not share eimerians, Levine and Ivens (1965) named the species first described by Dorney (1962) as E. dorneyi. Later, Soon and Dorney (1969) added additional mensural data for $E$. dorneyi oocysts they found in the same host species in Ontario, Canada. However, neither they nor Levine and 

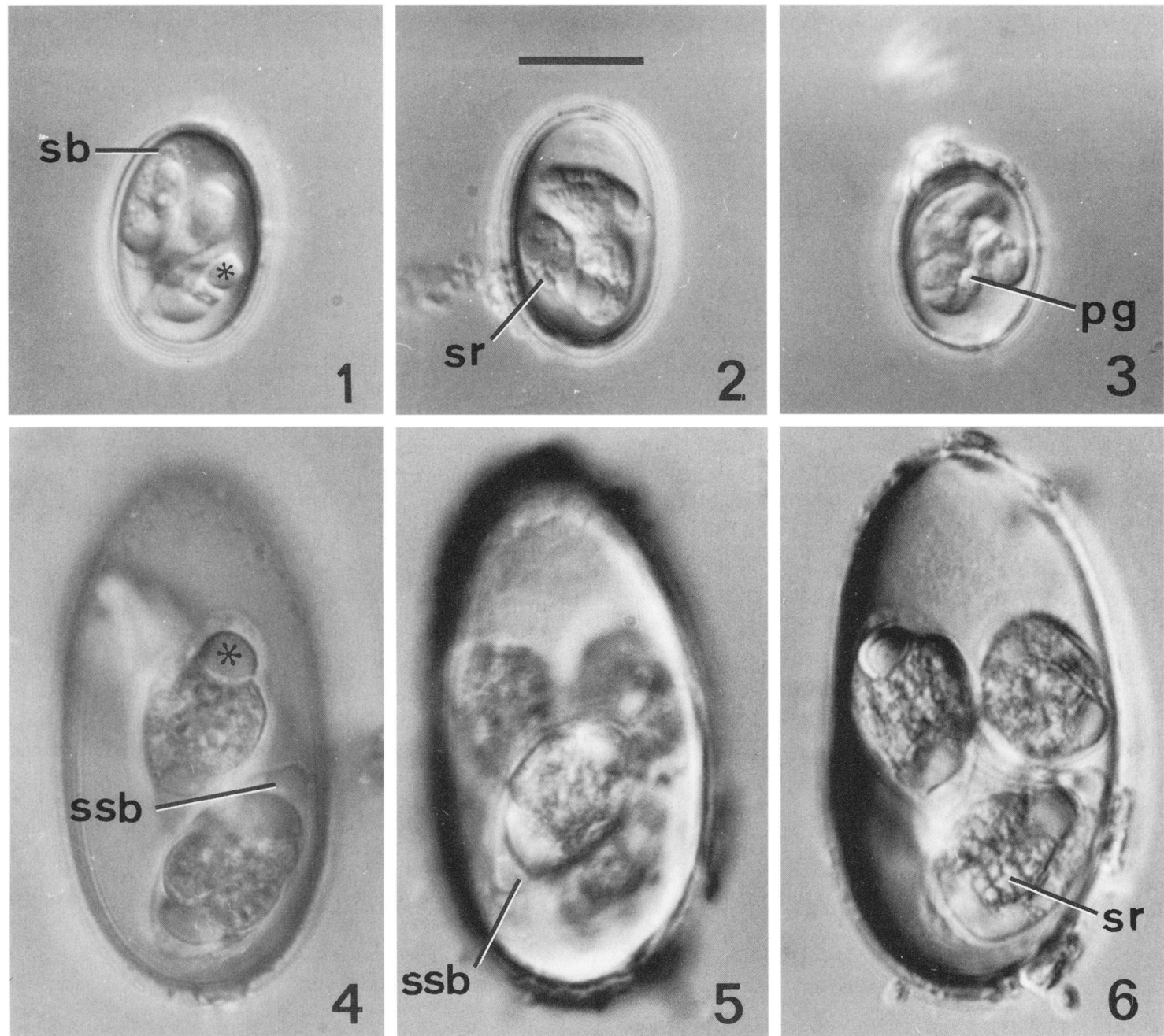

FIGURES 1-6. Photomicrographs of sporulated oocysts of coccidians recovered from the feces of Glaucomys sabrinus captured in the MacDonald Forest, Benton County, OR. 1-3. Eimeria dorneyi. 4-6. Eimeria bentoniensis n. sp. Scale bar $=10 \mu \mathrm{m}$ for all figures. Abbreviations: pg, polar granule; sb, Stieda body; sr, sporocyst residuum; ssb, substieda body; *, sporozoite refractile body.

Ivens (1965) submitted a photomicrograph (=hapantotype) for reference into an accredited museum, a procedure not consistent with the intent of the International Code of Zoological Nomenclature (Ride et al. 1985 ) that explicitly recommends the designation of type specimens for new species (see Bandoni and Duszynski [1988] for a complete discussion). Here, we provide structural information to supplement that given by Soon and Dorney (1969) and provide phototypes/hapantotypes (deposited in an accredited museum) of sporulated oocysts (see Article 72 (3) (iv), p. 143-144 in Ride et al. [1985]). We also provide a line drawing to supplement/replace the one in Soon and Dorney (1969) because their recorded mensural data note the presence of a sporocyst residuum that did not appear in their drawing.

\section{Eimeria bentoniensis $\mathbf{n}$. sp.}

(Figs. 4-6, 8)

Oocysts ellipsoidal, pointed at 1 end, with 2 walls, $\sim 1.5$, of equal thickness, outer layer smooth (Fig. 4), but often has adherent debris attached (Figs. 5, 6); micropyle and oocyst residuum absent; polar granule absent/present, $0-2$, usually 1 ; sporulated oocysts $(\mathrm{N}=28) 41-52$ $\times 22-31(47.2 \times 25.0)$ with $\mathrm{L}: \mathrm{W}$ ratio $1.6-2.2(1.9)$; sporocysts $(\mathrm{N}=$ 26) ovoidal, pointed at Stieda body, 17-21 × 9-11 $(19.0 \times 10.5)$ with $\mathrm{L}: \mathrm{W}$ ratio $1.5-2.2(1.8)$; Stieda body pointed and substieda body present, $\sim 2 \times$ wider than Stieda body, but parastieda body absent; sporocyst residuum of coarse granules and appears membrane bound, $\sim 7.5$ in length; 1 large refractile body present, $\sim 1 / 2$ the length of the sporozoite.

\section{Taxonomic summary}

Type host: Glaucomys sabrinus Shaw 1801, northern flying squirrel. Type locality: U.S.A., Oregon, Benton Co., MacDonald Forest, $44^{\circ} 37.63^{\prime} \mathrm{N}, 123^{\circ} 18.28^{\prime} \mathrm{W}$.

Prevalence: Found in 1/11 (9\%) G. sabrinus captured for the first time and subsequently found in 2 animals recaptured at a later date.

Sporulation time: Within $1 \mathrm{wk}$ at room temperature $(20 \mathrm{C})$.

Material deposited: Phototypes of sporulated oocysts in the USNPC, Beltsville, Maryland, no. 86933. Symbiotypes were not collected.

Etymology: The nomen trivale is derived from the type locality (county) and -iensis ( $\mathrm{L}$., belonging to).

\section{Remarks}

Only Eimeria petauristae from the Himalayan flying squirrel, Petaurista petaurista, in India (Ray and Singh, 1950) approaches the size of our new species, but its sporulated oocyst has a distinctive flask shape with a short neck, a dome-shaped "pseudomicropyle" with a transparent outer cap, and a rugged deep brown outer wall layer, all of which the new species lacks. Also, the sporocysts of our species have both Stieda and substieda bodies, which the sporocysts of E. petauristae lack. The 3 flying squirrels infected with E. bentoniensis were also infected with $E$. dorneyi. 

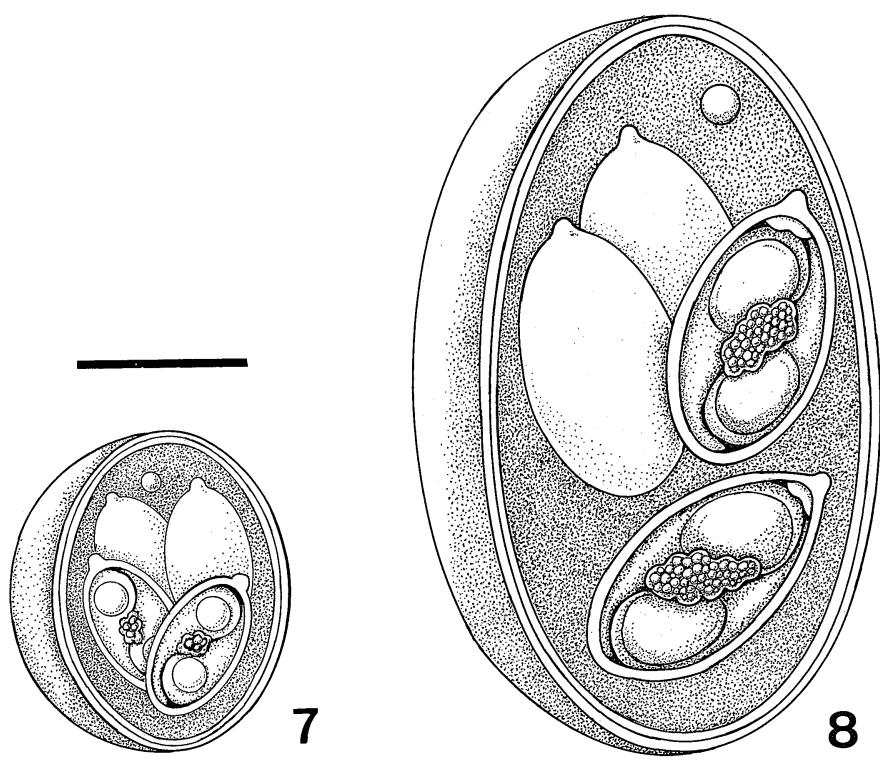

Figures 7, 8. Composite line drawings of sporulated oocysts of coccidians from the feces of Glaucomys sabrinus. 7. Eimeria dorneyi. 8 Eimeria bentoniensis. Scale bar $=10 \mu \mathrm{m}$.

\section{Eimeria vilasi Dorney, 1962}

The oocysts we saw were slightly larger $(=21.6 \times 17.9$ vs. $17.6 \times$ 14.3) than those in Dorney's (1962) original description and the sporocysts also were proportionally larger $(=11.8 \times 6.3$ vs. $10.1 \times 5.6)$, but the L:W ratios match and other structural and qualitative features were identical to those of E. vilasi. Given the broad host range of most sciurid eimerians, especially between species in 1 genus (Seville and Stanton, 1993; Wilber et al., 1994) and also between host species in different genera (Shults et al., 1990; Thomas and Stanton, 1994), it is unlikely that the form we saw was something other than E. vilasi. This species was found in 19 of 30 (63\%) chipmunks captured for the first time. The prevalence of E. vilasi in 1990 was lower than in 1991 (46 vs. $76.5 \%$ ), and more male than female hosts were infected at first capture in both years (67 vs. $0 \%$ in 1990; 85 vs. $33 \%$ in 1991). Fifteen of 30 animals were recaptured at least once ( $=5.5$ captures), and 13 of these were infected more than once (captures infected $=68 \%$ ).

\section{DISCUSSION}

We address 2 questions in this study: (1) can we potentially learn anything about the biology/ecology of the eimerians in the hosts sampled, and (2) what are the valid species of eimerians infecting flying squirrels?

Four flying squirrels and 13 chipmunks that were recaptured in this study showed evidence of either continuous or repeated infections. This suggests that these sciurids did not develop complete (sterile) immunity to E. dorneyi and E. vilasi. Stanton et al. (1992), Seville and Stanton (1993), and Wilber et al. (1994) found little evidence of complete immunity in ground squirrels (Spermophilus elegans and Spermophilus townsendii) and suggested that some ground squirrel eimerians may be "commensals." In support of this conclusion, Seville et al. (1992) did not find negative effects of experimental Eimeria infection on nutrient assimilation in S. elegans. In a parallel study, Fuller (1996a, 1996b) found evidence of partial immunity to Eimeria arizonensis in deer mice, although complete immunity seemed to occur infrequently. However, partial immunity to eimerians has not been studied in free-ranging sciurids.
The prevalence of E. vilasi was higher in male than in female chipmunks in both years of this study. Female mammals may be less susceptible to disease than males because androgens suppress immunity (Schuurs and Verheul, 1990; McGruden and Stimson, 1991). In addition, males may be exposed to parasites more frequently than females because of behavioral or microhabitat differences (Alexander and Stimson, 1988; Bundy, 1988). It is unclear which of these factors is important in determining the prevalence of E. vilasi in T. townsendii, or whether both may be working in concert.

The subfamily Pteromyinae contains 14 genera of flying squirrels (Wilson and Reeder, 1993), including the North American flying squirrels, G. sabrinus and $G$. volans. Only 7 species of Eimeria have been described previously in the Pteromyinae: Eimeria glaucomydis Roudabush, 1937 from Glaucomys volans in Iowa, U.S.A. (Roudabush, 1937); E. petauristae Ray and Singh, 1950 from $P$. petaurista in India (Ray and Singh, 1950); Eimeria parasciurorum Bond and Bovee, 1958 from $G$. volans in Florida, U.S.A. (Bond and Bovee, 1958); Eimeria dorneyi Levine and Ivens, 1965 in G. volans from Wisconsin, U.S.A. (Dorney, 1962; Levine and Ivens, 1965); Eimeria aeromysis Colley and Mullin, 1971 in Aeromys tephromelas from Johore, Malaysia (Colley and Mullin, 1971); Eimeria hylopetis Colley and Mullin, 1971 in Hylopetes spadiceus from Kuala Lumpur, Malaysia (Colley and Mullin, 1971); and Eimeria malayensis Colley and Mullin, 1971 in Petaurista elegans (type host) and in $P$. petaurista from Kuala Lumpur, Malaysia (Colley and Mullin, 1971). Thus, E. bentoniensis and E. dorneyi are the first eimerians reported from $G$. sabrinus.

\section{ACKNOWLEDGMENTS}

We thank D. H. Olson, U.S. Forest Service and M. McDowell, Corvallis, Oregon, for technical and field assistance as well as many undergraduates in the Zoology Department at Oregon State University for their assistance in collecting field data. This work was supported, in part, by the OSU Zoology Research Fund to C.A.F. and, in part, by NSF-PEET grant (DEB9521687) to D.W.D. Finally, we thank Beth Dennis, Biology Department, The University of New Mexico, for the line drawings.

\section{LITERATURE CITED}

Alexander, J., And W. H. Stimson. 1988. Sex hormones and the course of parasitic infections. Parasitology Today 4: 189-193.

Ash, L. R., AND T. C. ORIHEl. 1987. Parasites: A guide to laboratory procedures and identification. ASCP Press, Chicago, Illinois, $328 \mathrm{p}$

Bandoni, S. M., And D. W. Duszynski. 1988. A plea for improved presentation of type material for coccidia. Journal of Parasitology 74: 519-523.

Bond, B. B., AND E. C. BoveE. 1958. A redescription of an eimerian coccidian from the flying squirrel, Glaucomys volans, designating it Eimeria parasciurorum nov. sp. Journal of Protozoology 4: 225229.

Bundy, D. A. P. 1988. Gender-dependent patterns of infection and disease. Parasitology Today 4: 225-229.

Colley, F. C., And S. W. Mullin. 1971. New species of Eimeria (Protozoa: Eimeriidae) from Malaysian squirrels. Journal of Protozoology 18: 400-402.

DORNEY, R. S. 1962. A survey of the coccidia of some Wisconsin Sciuridae with descriptions of three new species. Journal of Protozoology 9: 258-261.

Frey, J. K., T. L. Yates, D. W. Duszynski, W. L. Gannon, and S. L. GARDNER. 1992. Designation and curatorial management of type 
host specimens (symbiotypes) for new parasite species. Journal of Parasitology 78: 930-932.

FULLER, C. A. 1996a. Variable levels of immunity to experimental Eimeria arizonensis infections in natural, semi-natural and laboratory populations of deer mice (Peromyscus maniculatus). Canadian Journal of Zoology 74: 750-757.

1996b. Population dynamics of two species of Eimeria (Apicomplexa: Eimeriidae) in deer mice (Peromyscus maniculatus): Biotic and abiotic factors. Journal of Parasitology 82: 220-225.

Galli-Valerio, B. 1932. Notes de parasitologie et de technique parasitologique. Zentralblatt fur Bakteriologie Erste Abtellung Originale 125: $129-142$.

Levine, N. E., AND V. IVens. 1965. The coccidian parasites (Protozoa, Sporozoa) of rodents. Illinois Biological Monographs no. 33. University of Illinois Press, Urbana, Illinois, $365 \mathrm{p}$.

MCGRUden, A. B., AND W. H. Stimson. 1991. Sex hormones and immune function. In Psychoneuroimmunology, R. Adler, D. L. Felton and N. Cohen (eds.). Academic Press, Inc., San Diego, California, p. 475-493.

RaY, H. N., AND H. Singh. 1950. On a new coccidium, Eimeria petauristae $\mathrm{n}$. sp. from the intestine of a Himalayan flying squirrel, Petaurista inornatus (Geoffery). Proceedings of the Zoological Society of Bengal 3: 65-70.

Ride, W. D. L., C. W. Sabrosky, G. Bernardi, and R. V. Melville (EDS.). 1985. International code of zoological nomenclature, 3rd. ed. H. Charlesworth and Co. Lte., Huddersfield, U.K., 338 p.

ROUDABUSH, R. L. 1937. Two Eimeria from the flying squirrel, Glaucomys volans. Journal of Parasitology 23: 107-108.

SChuURS, A. H. W. M., AND H. A. M. Verheul. 1990. Effects of gender and sex steroids on the immune response. Journal of Steroid Biochemistry 35: 157-172.
Seville, R. S., H. J. Harlow, N. L. Stanton, and M. L. Wagner. 1992. Effects of eimerian (Apicomplexa: Eimeriidae) infections on nutrient assimilation in the Wyoming ground squirrel. Journal of Parasitology 78: 881-885.

- AND N. L. Stanton. 1993. Eimerian guilds (Apicomplexa: Eimeriidae) in Richardson's (Spermophilus richardsonii) and Wyoming (Spermophilus elegans) ground squirrels. Journal of Parasitology 79: 973-975.

Shults, L. M., R. S. Seville, N. L. Stanton, and G. Menkens. 1990. Eimeria sp. (Apicomplexa: Eimeriidae) from Wyoming ground squirrels (Spermophilus elegans) and white-tailed prairie dogs ( $C y$ nomys leucurus) in Wyoming. Great Basin Naturalist 50: 327-331.

SOON, B.-L., AND R. S. DoRNEY. 1969. Observations on a coccidium (Eimeria dorneyi) from the northern flying squirrel in Ontario. Bulletin of the Wildlife Disease Association 5: 37-38.

Stanton, N. L., L. M. Shults, M. Parker, and R. S. Seville. 1992. Coccidian assemblages in the Wyoming ground squirrel, Spermophilus elegans. Journal of Parasitology 78: 323-328.

Thomas, D. M., and N. L. Stanton. 1994. Eimerian species (Apicomplexa: Eimeriidae) in Gunnison's prairie dogs (Cynomys gunnisoni zuniensis) and rock squirrels (Spermophilus variegatus grammurusi) from southeastern Utah. Journal of the Helminthological Society of Washington 61: 17-21.

Wilber, P. G., B. Hanelt, B. Van Horne, and D. W. Duszynski. 1994 Two new species and temporal changes in the prevalence of eimerians in a free-living population of Townsend's ground squirrels (Spermophilus townsendii) in Idaho. Journal of Parasitology 80: 251-259.

WiLson, D. E., AND D. A. M. Reeder. 1993. Mammal species of the world, a taxonomic and geographic reference, 2nd ed. Smithsonian Institution Press, Washington D.C., p. 419-465. 